\title{
INDIAN BEAUTY AND FOREIGN SPIRITS: THE GOLDEN CASKET IN THE MERCHANT OF VENICE
}

\section{Clayton MacKenZIE}

\author{
School of Communication, International Studies, and Languages \\ University of South Australia, Magill Campus, Adelaide, Australia \\ e-mail: clam64clam@gmail.com
}

\begin{abstract}
The casket scenes in The Merchant of Venice are powerful arbiters of success and failure. The casket challenge is loaded with culturally-specific signifiers which favour local contenders. Bassanio rejects the gold casket because he is aware that European moral iconographies repudiate earthly wealth (though, ironically, Bassanio is a poor illustration of the principle). The Prince of Morocco, by contrast, understandably supposes gold to be an appropriate metaphor for love - gold was, after all, the prima materia of North Africa. Morocco is on every level more worthy than Bassanio but fails because he chooses through foreign eyes.
\end{abstract}

Key words: Shakespeare, caskets, iconography, gold, fortune, Bassanio, Morocco, Portia.

Portia's suitors in The Merchant of Venice must choose between gold, silver and lead caskets in order to determine the casket "wherein I am contain'd" (Portia, II.ix.5) 1 . Suitors from near and far venture their luck, only for the fortune-seeking local boy from Venice, Bassanio, to win the contest. It is a lottery and lotteries are not won or lost on merit but there is more than a pinch of irony in Bassanio's success. The young man has tapped the cash-strapped Antonio for money to make the trip to Belmont; and he makes it clear that his primary objective is Portia's money. Yet, where choosing the gold casket might seem his obvious route, instead he chooses lead. This essay will look particularly at the golden casket which is rejected by Bassanio but selected by the Prince of Morocco, evaluating the reasons the two men give in making their respective decisions. It will argue further that being local works to Bassanio's benefit. The casket challenge, set by Portia's father, is loaded with culturally-specific signifiers which inevitably favour local contenders, however worthy their foreign competitors may be.

\footnotetext{
${ }^{1}$ All references to Shakespeare's text are from Blakemore et al. (1997).
} 
Rejecting the golden casket, Bassanio reasons that

those crisped snaky golden locks,

Which make such wanton gambols with the wind

Upon supposed fairness [are] often known

To be the dowry of a second head,

The skull that bred them in the sepulchre.

Thus ornament is but the guiled shore

To a most dangerous sea; the beauteous scarf

Veiling an Indian beauty

$$
\text { (III.ii.92-99) }
$$

In framing his rejection of the gold casket, Bassanio conflates three common Renaissance European understandings: the familiar image of Occasion (equated with Fortuna in 16th-century iconography, see Kiefer 1979), with flowing locks and scarf, standing on a floating ship's helm; a history of mediaeval and Renaissance representations of Fortuna with a deceitful double face (Frakes 1927; Kiefer 1983); and the customary equation of "India" with all things beautiful and rich (Malviya - Vanjare-Gupta 2009). That Bassanio reaches for the Fortuna topos is reasonably straightforward. The scroll of the gold casket is secured through the eye socket of a death's head, and premature death was axiomatically connected with Fortuna. There were some dissenters to this view. Machiavelli, for example, averred that "fortune is a woman... And therefore, like a woman, she is always a friend to the young, because they are less cautious, fiercer, and master her with greater audacity" (Machiavelli 1940, p. 94). But Machiavelli was viewed with suspicion by Elizabethans, and a litany of post-1550 commentators disagreed with his judgement, suggesting that Fortuna was a calamitous and deathly force to be avoided at all costs. ${ }^{2}$ What is disconcerting is Bassanio's allusion to the "beauteous scarf / Veiling an Indian beauty", an image that is apparently sullied by its association with the Occasion/Fortuna iconography. The allusive dissonance jars with the generally high estimation of India in the Elizabethan psyche. ${ }^{3}$ Bassanio had much to be grateful for when it came to India. Even if he had taken less interest in the voyages of discovery than his contemporaries, he would have known that his benefactor, Antonio, had his wealth locked into a merchant fleet returning from sundry

${ }^{2}$ See, for example, the frontispiece of Record (1556); and also Achille Bocchi's emblem LXXI ("OCCASIONEM QVI SAPIS NE AMISERIS") in Symbolicarum Quaestionum (1574).

${ }^{3}$ Allusions to India in Shakespeare's canon are overwhelmingly positive, focussing on the rarity and worth of India and its people: "as bountiful / As mines of India" (1 Henry IV, III.i.166167); "Her bed is India, there she lies, a pearl" (Troilus and Cressida, I.i.100); "in the spiced Indian air" (A Midsummer Night's Dream, II.i.124); "diamonds and Indian stones" (3 Henry VI, III.i.63). India was a topical issue in Elizabethan England which, at the time Shakespeare was writing The Merchant of Venice, was formalising its trading relationship with southern India through the establishment of the East India Company. The Portuguese were traditional allies of England and by 1600 their ships had plied the Carreira da India (the Passage to India) well over a thousand times, delivering goods to wealthy European households. They had established colonies from Goa on the east coast of India to Macao on the southern Chinese mainland of such size and permanence that some warned of a dangerous depopulation of the colonial metropole (see Drew-Bear 1994, p. 94). 


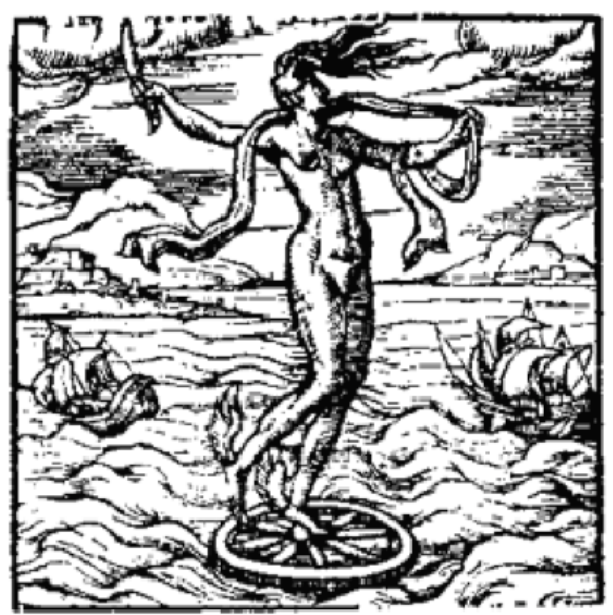

Figure 1. Geffrey Whithey's "In occasionem” (p. 181), A Choice of Emblemes. Leyden, 1586

exotic places, including the Indies ("he hath an argosy bound to Tripolis, another to the Indies" observes Shylock at I.iii.18-19). His mind made up, he rejects the gold casket and, with it, the bounty of Indian beauty. And, worse than that, in his reference to a "beauteous scarf / Veiling an Indian beauty", and his earlier allusion to "the dowry of a second head", he apparently compounds the insult by setting up discordant resonances with two emblematic topoi that would have been immediately recognisable to many Elizabethans. The first is Geffrey Whitney's 1586 print "In occasionem" (see Figure 1), presented in A Choice of Emblemes, the most popular English emblem book of the late 16 th century (Whitney 1586). The second is the traditional mediae$\mathrm{val} /$ Renaissance representation of Fortuna with snaky hair and a double face (Figure 2), most notably presented in John Lydgate's Tudor vulgate The Fall of Princes (Lydgate 1554). Whitney's print, copying Andrea Alciati's 1529 original $^{4}$, represents Occasion/Fortuna in familiar emblem book guise. ${ }^{5}$ She stands precariously on a floating ship's helm to signify her instability; the back of her head is shaved to suggest that once she has flown she may never be caught again; her nakedness is alluring but dangerous, for though she carries in one hand a "beauteous scarf", in the other she holds a deadly razor. Her whimsical favours are represented by two ships in the background - while one prospers, the other sinks. Lydgate's print is equally revealing. For-

${ }^{4}$ Alciati $\left(1531\right.$, sig. A $8^{r}$ ) produced more sophisticated versions of the same print in his later career, such as that recorded in Tozzi's 1621 Paduan assemblage of Latin prints originally published in the period 1534-1551. Alciati had a profound influence on his many collaborators and imitators who included Daza, Marquale, Hunger, Lefèvre, and, of course, Whitney, who all produced versions of this woodcut.

${ }^{5}$ For example, the image was copied by the Theodore de Bry in Emblemata (1592). As in Alciati's original, De Bry's Fortuna stands on a ball, her snaky locks blowing in the breeze. De Bry's device turns her scarf subtly into a sail, underscoring the sense that she will billow in whichever direction the fickle winds decree. 


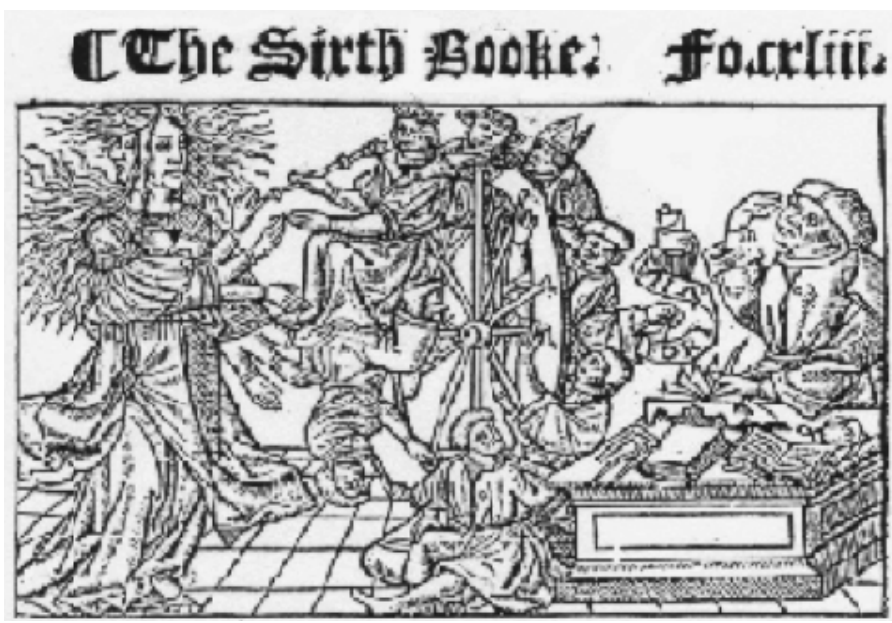

Figure 2. Woodcut of Fortuna (f. 143v)

in John Lydgate's The Fall of Princes. London, 1554

tuna stands before her wheel, those who aspire to her greatness gazing upon her in desperate hope. Only the abject beggar who sits at the base of the wheel deliberately looks the other way - for he now understands the treachery of her "guiled shore". Her "crispy snaky golden locks" are blown by the wind in all directions, suggesting a fickle nature. And more compellingly, the back of her head reveals what Bassanio calls a "second head", suggesting her treachery. Why does Bassanio meld these unsavoury Fortuna nuances with the worth and propriety of an "Indian beauty"? John Russell Brown suggests the term mirrors the "Elizabethan aversion to dark skins" (Brown 1977, p. 82). He sees it as a racial slur, and he refers to negative allusions to Egyptians and Ethiopians elsewhere in Shakespeare. Blakemore Evans, in the Riverside Shakespeare similarly construe "Indian beauty" as a disparaging reference, citing as evidence the claim that "Elizabethans had a particular dislike for dusky skins" (Blakemore et al. 1997, p. 304).

But while Egyptians, Ethiopians, Turks, Jews, Frenchmen and a host of other ethnic, religious and national groups are racially lambasted in Shakespeare, Indians are not. There is a "base Indian, [who] threw a pearl away / Richer than all his tribe" (V.ii.347-348), but the point is that his wanton spite would have rendered him "base" even in the eyes of his own people. In Henry VIII there is an "Indian with a great tool" (V.iii.34) but to a bawdy Jacobean audience this would hardly have been construed negatively; and Helena's claim to be "Indian-like, / Religious in mine error" (I.iii.204205) in All's Well That Ends Well has nothing to do with physical appearance or worth. In As You Like it, probably written within twelve months of The Merchant of Venice, Rosalind reads a poem she has discovered mysteriously pinned to a tree in the Forest of Arden:

"From the east to westerne Inde, No jewel is like Rosalinde. 
Her worth, being mounted on the wind, Through all the world bears Rosalind..."

(III.ii.88-91)

As deliberately amateurish as Orlando's poem may be, its sentiments represent India as a place of peerless physical beauty - a yardstick against which the poet measures the beauty and worth of Rosalind.

It seems most unlikely that Bassanio's reference to "an Indian beauty" (III.ii.99) is a racial slur. A more plausible explanation is that this "Indian beauty" stands for an Asiatic Occasion, her demeanour and accoutrements closely aligned with Whitney's Occasion and the sense of maritime deceit:

Thus ornament is but the guiled shore

To a most dangerous sea; the beauteous scarf

Veiling an Indian beauty

$$
\text { (III.ii.97-99) }
$$

At the heart of Whitney's emblem, and of Alciati's woodcut before it, lies the sense of beguilement, of extravagant danger hidden by a beauteous veneer. This is not a warning that an "Indian beauty", per se, is a mortal threat but that the exotic persona of an Asiatic Occasion is a force of dire imperilment. The exoticism of gold, and perhaps the thoughts of Antonio's argosy plying its way back from the Indies, encourage him to orientalise his bodily sense of Fortuna. Bassanio rejects the gold casket in Indian terms not because he is a racist or a bigot but because its allurement is too beautiful, too dangerous, too obviously framed in the context of a death's head.

That said, The Merchant of Venice packs more xenophobia into its text and storyline than most Elizabethan dramatic works and perhaps Bassanio's victory in the casket scene is part of the play's inexorable triumph of locals over aliens. If so, Shakespeare seeds the winds of victory with unmistakable irony. Take, for example, the Prince of Morocco, another suitor, who understands well enough the sway of fortune. He comes before the caskets "To try my fortune" (II.i.24), admits he might fail because "the greater throw / May turn by fortune from the weaker hand" (II.i.33-34), and concedes "blind Fortune [is] leading me" (II.i.42). There is much to admire about Morocco: he is intelligent, poetically articulate, educated, insightful, an incurable romantic and, to his credit, uninterested in Portia's money. But as a black, non-Venetian, Muslim contesting the hand of Portia in a fiercely European space we might guess his chances of success are slim. And we would be right. That is one of several sharp injustices The Merchant of Venice promotes in the intellectual after-burn of performance - for surely it is Morocco, with his passion and repartee, who deserves to win the hand of Portia. And yet just as surely, before he even chooses, we know there is not the slightest chance that his venture will succeed.

Morocco favours the gold casket partly because it plays into his narrative of Portia's veneration and partly because his culture esteems the beauty of gold beyond all material things: 
Let's see once more this saying grav'd in gold:

"Who chooseth me shall gain what many men desire":

Why, that's the lady, all the world desires her.

From the four corners of the earth they come

To kiss this shrine, this mortal breathing saint.

The Hyrcanian deserts and the vasty wilds

Of wide Arabia are as throughfares now

For princes to come view fair Portia.

The watery kingdom, whose ambitious head

Spets in the face of heaven, is no bar

To stop the foreign spirits, but they come

As o'er a brook to see fair Portia.

$$
\text { (II.vii.36-47) }
$$

The difference between Bassanio and the Prince of Morocco is somewhat akin to the difference between Bassanio and Antonio. Bassanio has travelled round the block with borrowed money to pursue Portia. Antonio and Morocco have sought their respective fortunes across oceans - even though Antonio is notionally a Venetian, they are both "foreign spirits", undaunted by Neptunian adversities. These are the same maritime adversities represented by flourishing and sinking ships in the backdrop to Whitney's print "In occasionem". It is not at all surprising that Antonio and Morocco are both alienated and, in a philosophical if not an actual sense, united in loss at the end of the play.

Bassanio's view that trusting the "Indian beauty" of the golden casket will prove fatal proves nearly-true in the case of the Prince of Morocco - he has vowed not to marry and his consequent inability to establish lineage will render a death of sorts. Morocco's rebuff is delivered by the casket inscription as a failure of wisdom:

"Had you been as wise as bold,

Young in limbs, in judgment old,

Your answer had not been inscroll'd.

Fare you well, your suit is cold."

$$
\text { (II.vii.70-73) }
$$

These are harsh words for a man who has just ventured across a sizeable chunk of the known world in pursuit of love; and all the more galling because he loses out to someone who has invested his energies in the search for material treasure. Bache and Loggins unkindly read Morocco's failure as sheer folly, paralleling it to Hector in Troilus and Cressida who "foolishly sacrifices himself for Greek armor and then, having achieved it, discovers that it contains a 'putrefied core' ... a rotten heart" (Bache-Loggins 1996, p. 227). But had Morocco been truly wise, rather than passionate and committed, he would have made no choice at all. He would have remained safe and sound in his palace in Marrakesh, and survived to find happiness in some other way. But survival and happiness are not the natural territory of the adventurousat-heart in The Merchant of Venice. They are aliens to Italian society, the foreign spir- 


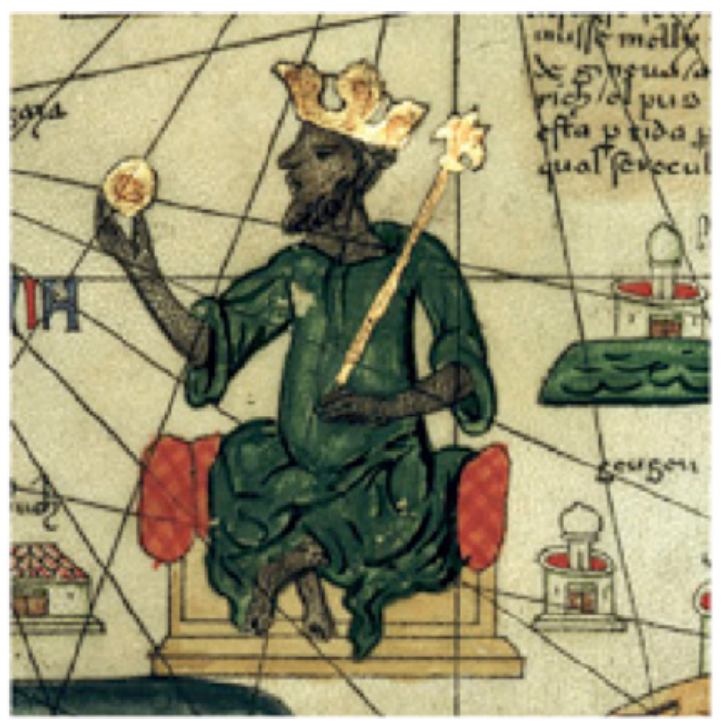

Figure 3. An African king, with gonden sceptre and crown, holding a huge gold nugget From a 15th-century facsimile copy in the British Library. Reproduced in The Trans-Saharan Gold Trade (7th-14th Century).

Heilbrunn Timeline of Art History. New York, The Metropolitan Museum of Art 2000-. http://www.metmuseum.org/toah/hd/gold/hd_gold.htm (Accessed in October 2000)

its destined to fail. Their adventurousness - be it the quest for friendship or love or acceptance - amounts to little.

Where does all this leave "an Indian beauty" and "foreign spirits"? Not in a particularly enviable place. Bassanio's "Indian beauty" is rejected because she reflects a fatal foreign adventurousness. The paradox is that Bassanio's prosperity has relied on Antonio's near-fatal Indian enterprise to win the hand of Portia - and the text makes little effort to hide or diminish this irony. Bassanio is not a man to risk fortune but, certainly, he is not averse to others risking fortune on his behalf. All that dooms Morocco in Act II seems to have aggrandised Bassanio in Act I. In winning Antonio's backing, Bassanio describes Portia as his "golden fleece" (Bassanio, I.i.172) (Peyré 1996) ${ }^{6}$ and yet it is lead, not gold, that he chooses in the casket scene. How can he get so much wrong, and yet that right? It could be because he is a Venetian and understands that the private esteem of gold is one thing but the crass public celebration of such is quite another. Whitney's 1586 print on the hazards of female beauty avers that "Poison is often drunk from golden cups" ("Sapius in auro bibitur veneneum") (Whitney 1586 , p. 79). That moral paradigm would have played strongly for an Elizabethan audience, even if the play setting was Italy. Bassanio's choice of the leaden casket is a guess, but one informed by the public moral posturing of the society in which he lives.

${ }^{6}$ In particular, Peyré evidences (p. 108) a link between the idea of the golden fleece and Elizabeth I as a prospective bride for the Duke of Alençon. 
It would have been vulgar for Portia's father to commodify his daughter as gold or even silver. The only real choice was the lead casket, as Bassanio knows only too well.

The Prince of Morocco chooses without the benefit of local cultural context. As an African prince, he quite reasonably supposes gold to be an appropriate metaphor for the quest of love - gold, after all, was and remains the prima materia of North Africa from the tomb of Tutankhamun to the ubiquitous gold markets of modern day Arabia (see Figure 3). A mistake easily made by the unfortunate potentate but with devastating consequences. Had he knowledge of the European emblem books, he might have avoided his fate - but how could he, an African man of passion and daring, know about such things? The unmistakable lesson of The Merchant of Venice is that exotic treasure, whether it takes the form of gold or beauty or wit or adventure, stands little chance of success in the close-knit, inward-looking Italy of Shakespeare's play. The flaw in Morocco's suit is not that he is unworthy or unwise but that he chooses his casket through the eyes of a foreigner.

\section{References}

Alciati, Andrea (1531): Emblematum Liber. Augsburg, Heinrich Steyner. sig. A $8^{\mathrm{r}}$.

Bache, William B.-Loggins, Vernon P. (1996): Shakespeare's Deliberate Art. Lanham-New York-London, The University Press of America.

Blakemore, Evans et al. (eds) (1997): The Riverside Shakespeare. 2nd editon. Boston, Houghton Mifflin.

Brown, John Russell (ed.) (1977): The Merchant of Venice. Arden edition. London, Methuen.

Drew-Bear, Annette (1994): Painted Faces on the Renaissance Stage: The Moral Significance of Face-Painting Conventions. Lewisburg, Bucknell University Press.

Emblemata (1592): Emblemata de Nobilitate et officio Heraldico. Frankfurt.

Frakes, Jerold C. (1927): The Fate of Fortune in the Early Middle Ages: The Boethian Literature. Cambridge, Massachusetts, Harvard University Press.

Kiefer, Frederick (1979): The Conflation of Fortuna and Occasio in Renaissance Thought and Iconography. Journal of Medieval and Renaissance Studies (Durham, NC) Vol. 9, pp. 1-27.

Kiefer, Frederick (1983): Fortune and Elizabethan Tragedy. Cambridge, Massachusetts, Harvard University Press.

Lydgate, John (1554): The Fall of Princes. London, Richard Tottell.

Machiavelli, Niccolo (1940): The Prince and The Discourses. New York, Random House.

Malviya, Ravikant - Vanjare, Smt. Deepti-Gupta, Ashish (2009): The Glimpses of India in Shakespeare's Plays. Shodh, Samiksha aur Mulyankan (International Research Journal) Vol. II, Issues 9-10. Accessed on 1 November 2014 at http://www.ssmrae.com/admin/images/ a210a3adb0acd9350578b305de537a19.pdf

Maquerlot, Jean-Pierre - Willems, Michèle (eds) (1996): Travel and Drama in Shakespeare's Time. Cambridge, Cambridge University Press.

Peyré, Yves (1996): Marlowe's Argonauts. In: Maquerlot-Willems (1996), pp. 106-109.

Record, Robert (1556): The Castle of Knowledge. London, R. Wolfe.

Symbolicarum Quaestionum (1574): Bononiae: apud Societatem Typographiae Bononiensis. (First publ. 1555.)

Whitney, Geffrey (1586): A Choice of Emblemes. Leyden, Christopher Plantin. 